\title{
Sculpting the brain
}

\section{Pablo Garcia-Lopez*}

Rinehart School of Sculpture (MFA), Maryland Institute College of Art (MICA), Baltimore, MD, USA

\section{Edited by:}

Idan Segev, The Hebrew University

of Jerusalem, Israel

Reviewed by:

Todd L. Siler, Psi-Phi

Communications, LLC

(dba Think Like a Genius,

LLC), USA

${ }^{*}$ Correspondence:

Pablo Garcia-Lopez, Rinehart

School of Sculpture (MFA)

Maryland Institute College of

Art (MICA), 1300 W Mount

Royal Avenue Baltimore, MD

21217, USA.

e-mail: caravaca1@gmail.com
Neuroculture, conceived as the reciprocal interaction between neuroscience and different areas of human knowledge is influencing our lives under the prism of the latest neuroscientific discoveries. Simultaneously, neuroculture can create new models of thinking that can significantly impact neuroscientists' daily practice. Especially interesting is the interaction that takes place between neuroscience and the arts. This interaction takes place at different, infinite levels and contexts. I contextualize my work inside this neurocultural framework. Through my artwork, I try to give a more natural vision of the human brain, which could help to develop a more humanistic culture.

Keywords: art, neuroscience, neuroculture, sculpture, metaphors, Cajal, mechanism, butterflies

\section{INTRODUCTION}

The development of neuroscience in the last century and in recent years has been very influential in many fields of knowledge such as economics, politics, law, philosophy, public relations, art, etc. Reciprocally, different disciplines of knowledge have also influenced the development of neuroscience and science as a whole, pointing out the important keystones of the neuroscientific agendas and also influencing scientific research from different sociocultural perspectives. This interwoven mix of different areas of knowledge has been essential to the rise of a neuroculture (Frazzetto and Anker, 2009) that is influencing our life under the prism of the latest neuroscientific discoveries. Furthermore, this neuroculture can have a significant impact on neuroscientists in their daily practice creating new ways of thinking that will influence their research. Especially interesting is the interaction that takes place between neuroscience and arts. This relationship takes place at diverse, infinite levels and contexts. Many artists have used discoveries, data, illustrations, paradigms or scientific methodologies guided by different goals, motifs, global and personal narratives, and mediums. Through their holistic artworks, they not only echo the latest scientific discoveries, but many times their works go beyond the nature and meaning of these discoveries, enriching them with their personal narratives, ambiguity or critical opinions of some aspects of neuroscientific research and opening a neurocultural dialog to a wider audience. Besides adding complexity, these artworks also add plasticity, subjectivity and intra-individual differences to the neuroscientific models. The personal experiences are many times hidden by the normative scientific method, and other times highlighted by the subjectivity of artists, are essential to add reality, complexity, and plasticity to the neuroscientific models. That is why I would like to explain my position as an artist at the junction between neuroscience and art.

\section{BRIDGING THE GAP BETWEEN NEUROSCIENCE AND ART THROUGH METAPHORS CAJAL NATURALIST METAPHORS}

My work as an artist is directly inspired by my experience as a neuroscientist. I completed my $\mathrm{PhD}$ in conjunction with the Museum Cajal, working with the original slides and scientific drawings of Santiago Ramon y Cajal (1852-1934). Besides being completely astonished by the historical and current neuroscientific concepts, and esthetics of his histological slides, drawings, (Garcia-Lopez et al., 2010), articles, and books, I was impressed by the great abundance of metaphors that he employed in his scientific writings. Possibly, even more impressive concerning Cajal's metaphors are their naturalistic and organic essence. Many of these metaphors could be considered rhetorical ornaments, although they also function as explanatory and even as heuristic tools for proposing his models and theories about brain functioning. As Lakoff and Johnson pointed out in their seminal book Metaphors We Live By (Lakoff and Johnson, 1980), metaphors are not just rhetorical figures of speech, but ways of thinking. Describing Cajal's approach to the brain, Sherrington wrote:

"A trait very noticeable in him was that in describing what the microscope showed he spoke habitually as though it were a living scene ... The intense anthropomorphism of his descriptions of what the preparations showed was at first startling to accept. He treated the microscopic scene as though it were alive and were inhabited by beings which felt and did and hoped and tried even as we do. It was personification of natural forces as unlimited as that of Goethe's Faust, Part 2. A nerve-cell by its emergent fiber "groped to find another"! We must, if we would enter adequately into Cajal's thought in this field, suppose his entrance, through his microscope, into a world populated by tiny beings actuated by motives and strivings and satisfactions not very remotely different from our own. He would envisage the sperm-cells as activated by a sort of passionate urge in their rivalry for penetration into the ovum-cell. Listening to him I asked myself how far this capacity 
for anthropomorphizing might not contribute to his success as an investigator."

(Canon, 1949; Freire and García-López, 2008)

The use of metaphors by scientists has been studied by many scholars to see the cultural and personal influences that model the scientific practice (Hyman, 1962; Young, 1985; Sontag, 1990; Todes, 1997, 2009; Otis, 2002). They are useful as heuristic tools, but they can also become dangerous traps and obstacles, which can lead to initial progress but later stagnation in science (Kuhn, 1962).

For Cajal, the neurons were the "butterflies of the soul" (Cajal, 1901), in his personal interpretation of the psyche's myth. He often named different morphological structures using naturalistic terms: star-cells of the cerebellum, claw endings of the granule cells, etc., and named different cells and cellular endings with plant names such as mossy fibers, climbing fibers, rosacea endings, and nest endings (Cajal, 1899-1904). He also related the development of neurons to plants when he successfully applied the ontogenic method to study the nervous system:

"Since the full grown forest turns out to be impenetrable and indefinable why not revert to the study of the young wood, in the nursery stage."

(Cajal, 1901)

Cajal related plants to neurons not only by their morphology and development, but also because of their physiology, advancing his theories about the plasticity of the nervous system:

\begin{abstract}
"As opposed to the reticular theory, the theory of the free arborization of the cellular processes that are capable of developing seems not only the most likely, but also the most encouraging. A continuous pre-established net-like a lattice of telegraphic wires in which no new stations or new lines can be created-somehow rigid, immutable, incapable of being modified, goes against the concept that all we hold of the organ of thought that within certain limits, is malleable and capable of being perfected by means of well-directed mental gymnastics, above all during its period of development. If we did not fear making excessive comparisons, we would defend our idea by saying that the cerebral cortex is similar to a garden filled with innumerable trees, the pyramidal cells, which can multiply their branches thanks to intelligent cultivation, sending their roots deeper and producing more exquisite flowers and fruits every day."
\end{abstract}

(Cajal, 1894; see also DeFelipe, 2006)

Cajal's organic metaphors may reflect many of his personal life experiences. Being born in a village (Petilla de Aragon, Navarra in Spain), being a naturalist and being an artist were part of adolescent experiences that would latter emerge on his science life inside the lab. Cajal's metaphors were also a product of his time. They reflect cultural, social, and personal narratives of the age they were created. Nowadays, these organic metaphors could be oldfashioned ${ }^{1}$ or even dead neuroscientific metaphors, if we compare them to many of the current mechanistic terms employed by

\footnotetext{
${ }^{1}$ Cajal terminology is indeed still in use as well as many other organic terms such as "dendritic tree" or "synaptic pruning", but the current trend is to employ more mechanistic terminology.
}

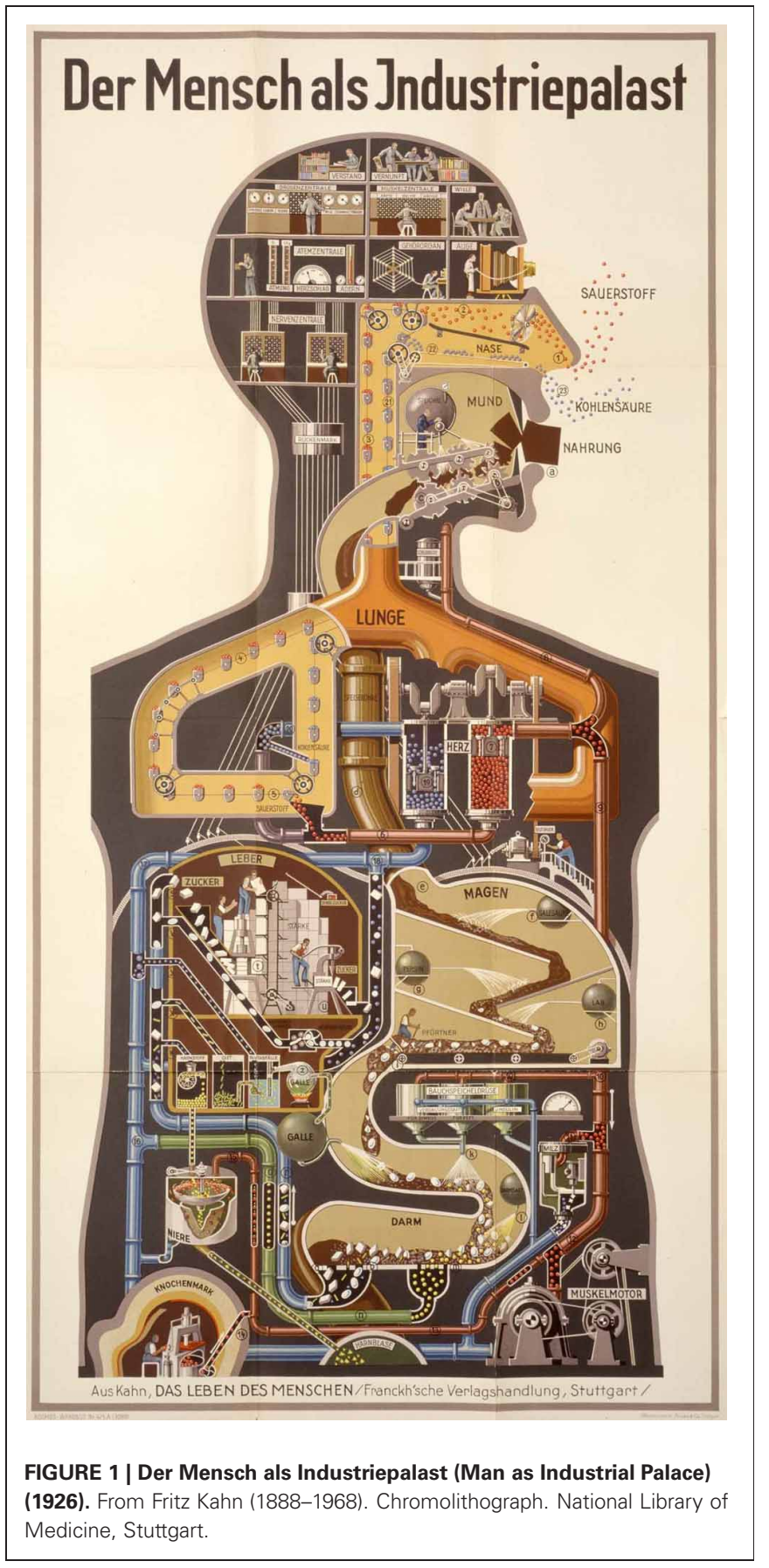

neuroscientists to refer to the brain (computational analogies, circuits, wires, cables, switching, firing, etc.) (Figure 1).

\section{ORGANIC METAPHORS VS. MECHANISTIC METAPHORS}

I do not want to transmit the perception that organic metaphors are more truthful, useful, or beautiful than the mechanistic ones. Mechanistic metaphors seem more objective than organic ones, but I believe comparing the brain to a computer has the same heuristic value as comparing the brain to a cauliflower. Depending on where you put the focus of your analysis, you will highlight or hide some important characteristics about 
the brain. Both systems of metaphors give us opposite, but complementary intellectual models, and both have their own esthetic beauty. For instance, it is interesting to note that the telegraph-nervous system model rejected by Cajal to explain the plasticity of the cerebral cortex was useful for Hodgkin and Huxley (1952) in their Nobel Prize-winning studies of nerve action potential generation and propagation. They used the differential equation that describes coaxial cable transmission (the spatiotemporal "Telegrapher's equation," which had been developed to model signal propagation for the design of the transatlantic undersea cable) (Daugman, 2001). Reciprocally, the use of brain's computer analogies has been very useful for the development of new technologies and important scientific fields like cybernetics and artificial intelligence (AI) research. These new technologies have also enhanced the development of neuroscience.

Although from a pragmatic point of view, the mechanistic metaphors can be more useful for scientists to continue their research about the brain, I find them negative as neurocultural products because they help to create a mechanical, deterministic, and reductionist vision of the human being. They hide some essential characteristics about the brain (natural origin, plasticity, self-organization, self-consciousness, emotional behavior, etc.). The vision of the nervous system that neuroculture creates is essential to envisioning ourselves and developing our life projects. From an educational perspective, I found more value to turn to another famous art-related metaphor of Cajal (1901) that envisions us as self-builders of our projects:

"Every man if he so desires becomes sculptor of his own brain."

Interestingly, in a sort of unconscious echo of this metaphor, the conceptual artist Jonathan Keats put his brain, as well as it's original thoughts up for sale. He registered a copyright of his brain as a sculpture created by him through the act of thinking. According to an interview with the BBC, he wanted to attain temporary immortality, on the grounds that the copyright act would give him intellectual rights on his mind for a period of 70 years after his death. He reasoned that, if he licensed out those rights, he would fulfill the "Cogito ergo sum" ("I think, therefore I $a m$ "), paradoxically surviving himself by seven decades. He then facilitated the sale by producing an exhibition and catalog at the San Francisco Modernism Gallery. The artwork consists of MRI images of his brain activity as he thought about art, beauty, love, and death (see also Frazzetto and Anker, 2009).

\section{THE SUCCESS OF MECHANICAL METAPHORS}

Using mechanistic models is not a new procedure, and it is inscribed in a long philosophical and scientific tradition

\footnotetext{
${ }^{2}$ Metaphors provide ambigous models of thinking. I interpret this sentence in the following way: it does not mean that you can make whatever you want with your brain (there are physical and material limitations to build a sculpture). It also does not reject the notion that education is essential to modulate your brain. But once you have that material that you have not conciously chosen, it is your own responsibility as a human to become a self-creator, through creativity and originality. This practice will allow us to become more human and not programmed machines.
}

(Descartes, 1664; La Mettrie, 1748) that has usually equated the brain-mind-nervous system to the latest technological innovation in every generation; the catapult by the Greeks (Searle, 1984), the telegraph ( $\mathrm{Du}$ bois-Reymond's idea released in a public lecture held in 1851, review in Otis, 2001), the jacquard loom (Sherrington, 1942), the telephone switchboard, the computer (Von Neumann, 1958).

Philosophical mechanism has been essential to reject the "élan vital" of vitalist philosophy. Once eliminated the vital sparks, energies, and spirits, mechanistic science became the new religion with their "objective" metaphors. Some disciplines such as cybernetics, AI research, and radical behaviorism have especially enhanced the mechanistic terms during the last century. It is still impressive how Skinner (1971) on the first chapter, A Technology of Behavior, of his book entitled Beyond Freedom and Dignity, tries to escape from the anthropomorphic metaphors of Psychoanalysis to start using his battery of mechanistic metaphors. In an era of mechanical objectivity, radical behaviorists found the best place to eliminate any kind of subjectivity of the human mind. Simply put, free will was considered an illusion. It was not until the visualization of the brain in action with new imaging techniques and the parallel development of cognitive neuroscience that the inside cognitive process of the mind/brain became again objective.

The behaviorist approaches were easily accepted and permeated many levels of society and educational systems. They were so resonant with human culture because we had already been transformed into machines before. The technology of behavior has been already in use in every society since ancient times: from the classical system of punishment and reward of education, religion, etc., to the more subtle strategies used today in social engineering. It facilitated the phenomenon of socialization and education despite being also at the ground of many antihumanistic positions that enhanced the use of man as a medium or machine. During the process of socialization, we were programmed to become cultural machines. The great achievement of radical behaviorists, mechanistic biologists, and some cybernetic approaches were to make us believe that even our nature was only mechanical. Through the abuse of mechanistic terms and analogies to refer to our body, brain, and physiological processes, we were transformed into cultural cyborgs.

Besides this conceptual and partial transformation of man to machine, we also assisted to deeper changes in the scientific practice, from Cajal's laboratory where he worked usually alone, to laboratories that are were envisioned as authentic factories ${ }^{3}$. Nowadays, science is one of the main important economic activities. Because of it's economic importance, the great competition, the race for arriving first to the new discovery, and many other reasons, many labs have become fabrics of science production. Depending on many aspects such as: the educational system, the country, the team principal investigator, among other factors, these factory lab models reject more or less the development of science creativity and originality to form robotic scientists with a high degree of specialization to produce very ambitious science

\footnotetext{
${ }^{3}$ In Cajal's time, there were also other labs managed as factories like Pavlov's lab (Todes, 1997).
} 
projects that require a lot of mechanical daily hard work, but with very few creative reward, especially for young scientists.

But of course, the transformations of society and culture of the last centuries did not only take place in the science education systems and scientific labs. The art studio was also transformed. Many machines and technologies became more used by artists, though art has always been linked to technology. Some art studios were transformed into art factories as soon as this notion of art became such an important socioeconomic industry. During last century, the number of assistants in art studios has increased, whereby transforming many studios into companies. The mechanical objectivity terminology also affected the language of artists. I was surprised of how some artists refer to themselves as object makers in order to highlight their craftsmanship activity. Of course, a painting or a sculpture is an object, but is it only that? Naming them only as objects removes any kind of spiritual value of the work; it only focused on the objective properties of the object. But what about the other characteristics of the artwork, such as the effort of the artist, the intention, the narrative, it's symbolic meaning, etc.?

\section{THE METAMORPHOSIS OF THE MACHINE INTO A BUTTERFLY}

I am also a mechanical product of this mechanistic culture and society. A mechanical product enhanced by science. I had this intuition that I had transformed myself into a machine while I was completing my bachelor in molecular biology. Before finishing, I realized I did not want to become a scientist. Through the excessive theoretical approach, dogmatism, memorization of data, and lack of experimentation inside the lab, I did not develop my scientific creativity and originality ${ }^{4}$. I have always considered myself a very creative person and furthermore, a person that needs to be creative to be happy. Although I did not develop my creativity as a scientist, as compensation to this excessive mechanization, my artistic creativity was enhanced. I had always made art at home, but it was not until this progressive mechanization that I started to feel the imperious necessity of creating art. This creativity and altered sensibility was also pointing to the necessity to express myself. Only very creative scientists can express themselves through their science as we have seen in the case of Cajal.

It was during a visit to the Venice Biennale (2003), during the last year of my bachelor, when I realized I wanted to mix science and art. There was an installation by the Israeli artist, Michal Rovner entitled, 'Against Order? Against Disorder?' at the Israel

\footnotetext{
${ }^{4}$ There are educational systems that do not promote the scientific creativity and originality. Creativity cannot be taught, but can be guided and stimulated. Some of these systems, with the excuse of being objective, reject creativity, imagination, and originality; and consider them as attributes of humanism. This is the first step to become a mechanical scientist.
}

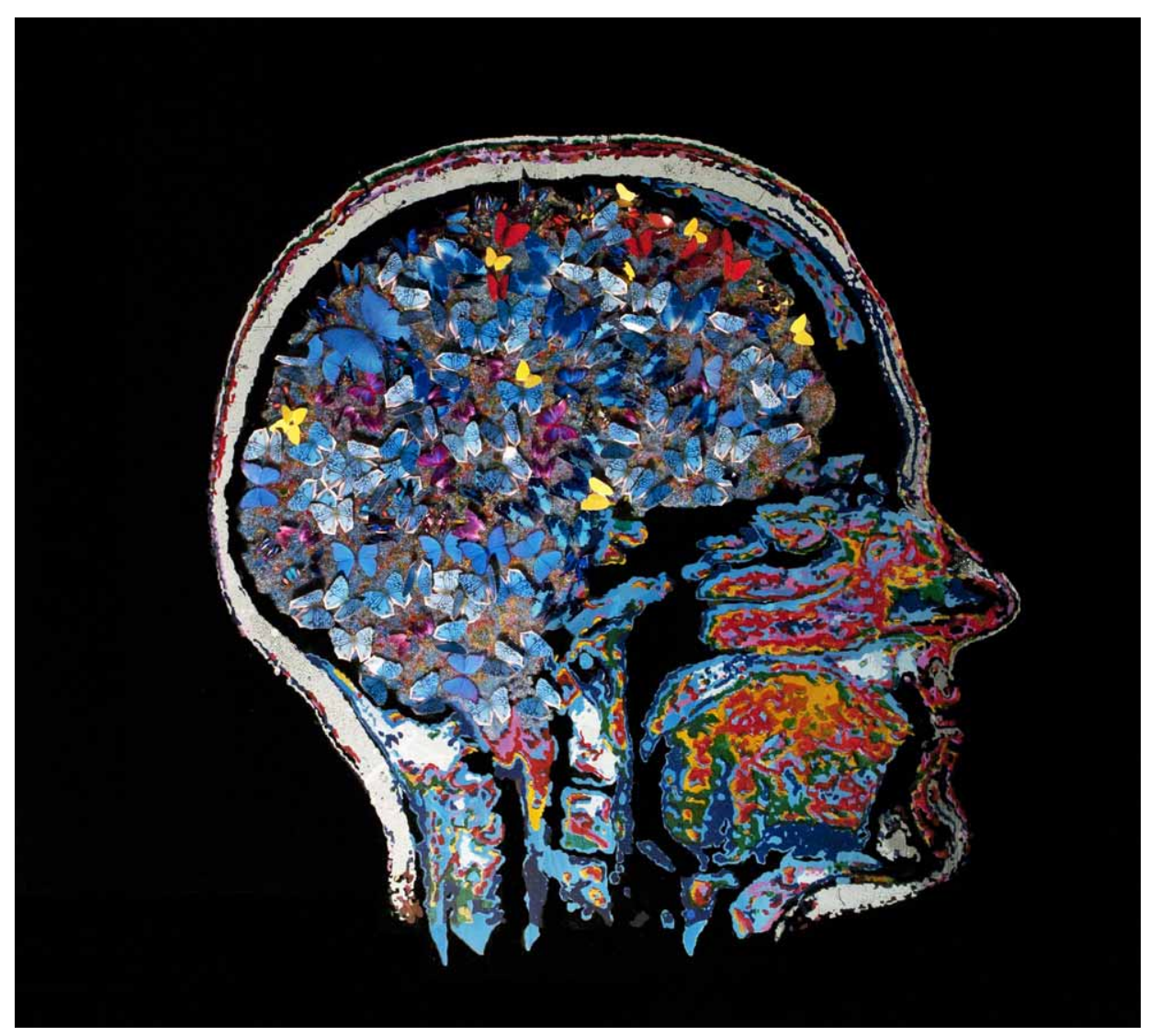

FIGURE 2 | PET soulbutterflies (2010). C-print and silkscreen on plexiglass. $1.20 \times 1.20 \mathrm{~m}$. 
Pavilion that was synthesizing the main ideas of molecular and evolutionary genetics, and social engineering in a very pleasant and instantaneous way. All the chromosomes, molecular cascades, cellular cultures, population genetics, eugenics, etc., were resonating in a single image. The main ideas I arrived through memorizing a great quantity of biochemical cascades, signaling pathways, etc., were already synthesized in a single image through a superposition of different visual metaphors. Furthermore, these ideas were amplified in very different and ambiguous ways that multiply the number of meanings and interpretations. For working in the interface between science and art, I decided to complete my PhD in Neuroscience. I wanted to learn more about science to have a better approach to the science and art interaction. I was lucky I could find the Museum Cajal, and besides obtaining my $\mathrm{PhD}$, I obtained the perfect link between my personal narrative and my global one.

Because of my Cajalian influence, I have been working with organic or naturalistic metaphors with a special goal in mind: I would like to enhance the public vision of the brain as a natural organ rather than as a mechanical and cybernetic one. It is a romantic yet lost battle to renaturalize the public perception of the brain through my artwork, but it is still worthy. As an artist, I started to work with some of the Cajalian metaphors such as "the neurons as butterflies of the soul" (Figure 2) $)^{5}$, or the "cortical garden" (see section 2.1) (Figure 3). That is also one of the reasons I usually work with silk (the product of the cocoons neuronsbutterflies) (Figure 4), a very fragile/resistant and plastic material related to the butterfly's metamorphosis or neuronal plasticity. Interestingly, silk has been recently used as a scaffold for neuronal grafts, regeneration, and remielinzation in the peripherical nervous system (Allmeling et al., 2008; Radtke et al., 2011).

These naturalistic metaphors are the starting point of my artwork. It is through the use of these concepts, intuitions, personal experiences, materials, mediums, and different methods (very much influenced by scientific experimentation) that I try to make my artwork. In the case of the sculpture "Silk explosion or how to destroy $10^{6}$ cocoons that will never become butterflies," (Figure 4), besides using silk, I also used a technical approach reminiscent of my microscopic observations. In this sculpture, the light plays an essential role catching the attention of the audience. The light is filtered through the shrinkfast transparent plastic

\footnotetext{
5 "Like the entomologist in search of colorful butterflies, my attention has chased in the gardens of the grey matter cells with delicate and elegant shapes, the mysterious butterflies of the soul, whose beating of wings may one day reveal to us the secrets of the mind."
}

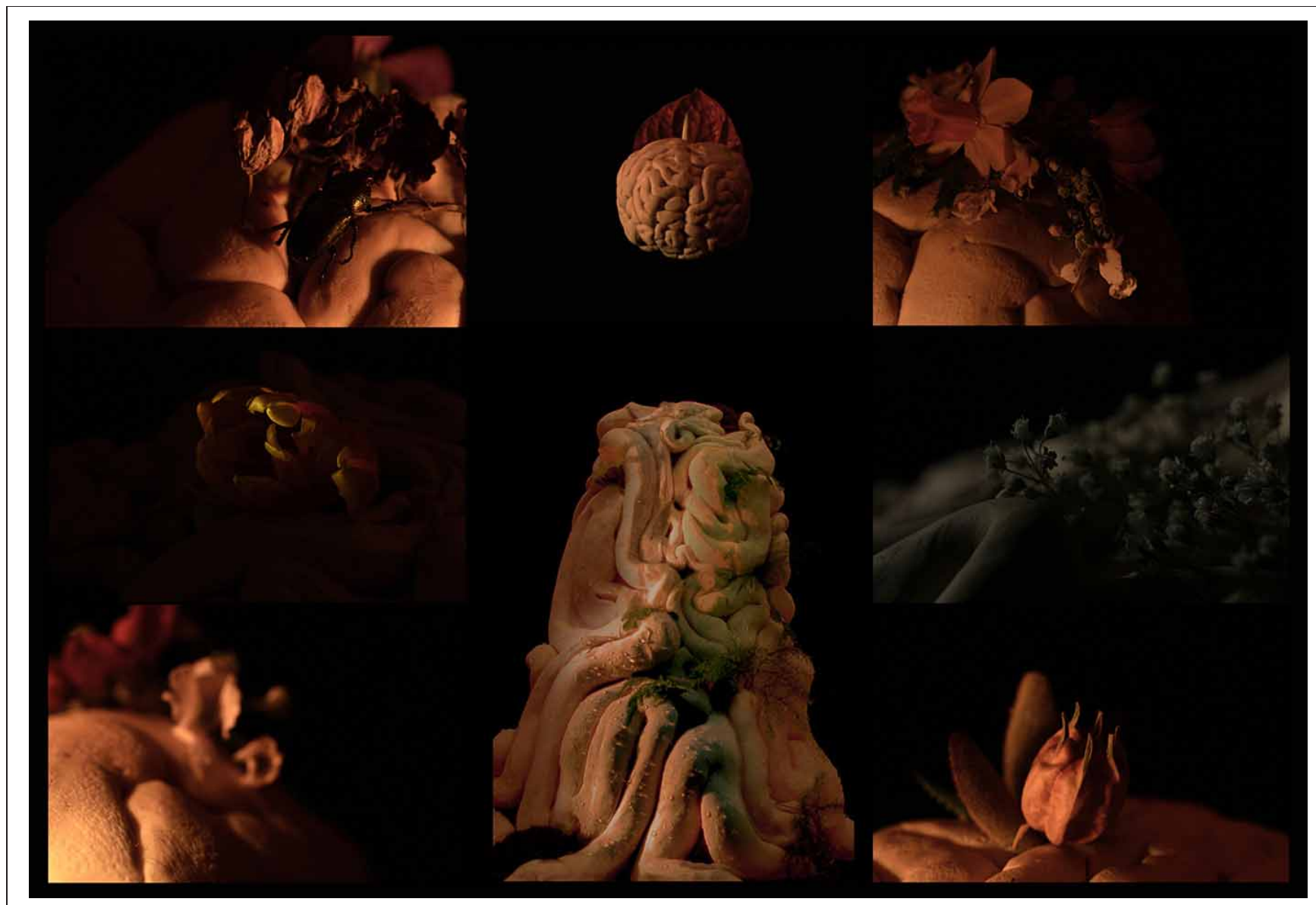

FIGURE 3 | The cortical garden (2009). Photo video installation: digital print on velvet paper and video (Dimension variable). 


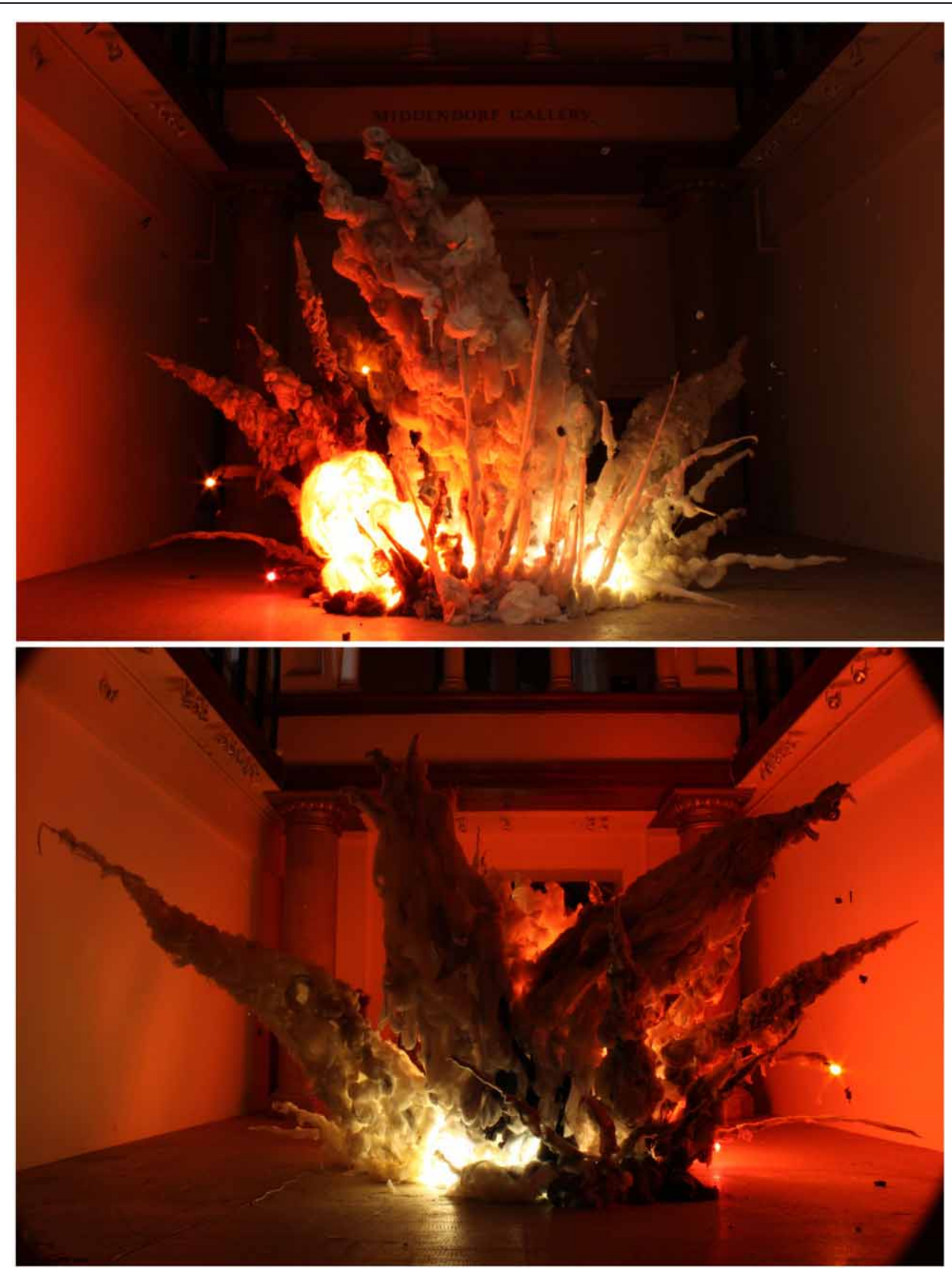

FIGURE 4 | Silk explosion or how to destroy $10^{6}$ cocoons that will never become butterflies (2011). Silk, MDF, electrical conduit, CFL ligthbulbs, plexiglass, shrink fast plastic. $6 \times 6 \times 3 \mathrm{~m}$. Middendorf Gallery (Baltimore).

scaffold and silk obtaining textures similar to the histological stainings like the Golgi method (Figure 5).

The global naturalistic narrative I explained overlaps with my personal narrative, which is to become the oil or petrol of my artistic machinery. Of course, art is a process of research and experimentation when many times I become detached from my initial narrative only to arrive to a new place that becomes the real artwork. It is a sort of paradigm shift, in scientific terms. This is not only important for my art practice but also for my life philosophy.
"When the perception you have from yourself does not fit with who you really are, and you develop a mechanical behavior, is the moment to look for a new experience to alter your state." 6

Step by step, I have abandoned this first-theoretical and metaphorical approach for a more experimental one. At the present time, I do not think too much in logical linear terms

${ }^{6}$ Free translation of the song Personalita Empirica by Franco Battiato, with lyrics by Manlio Sgalambro. 

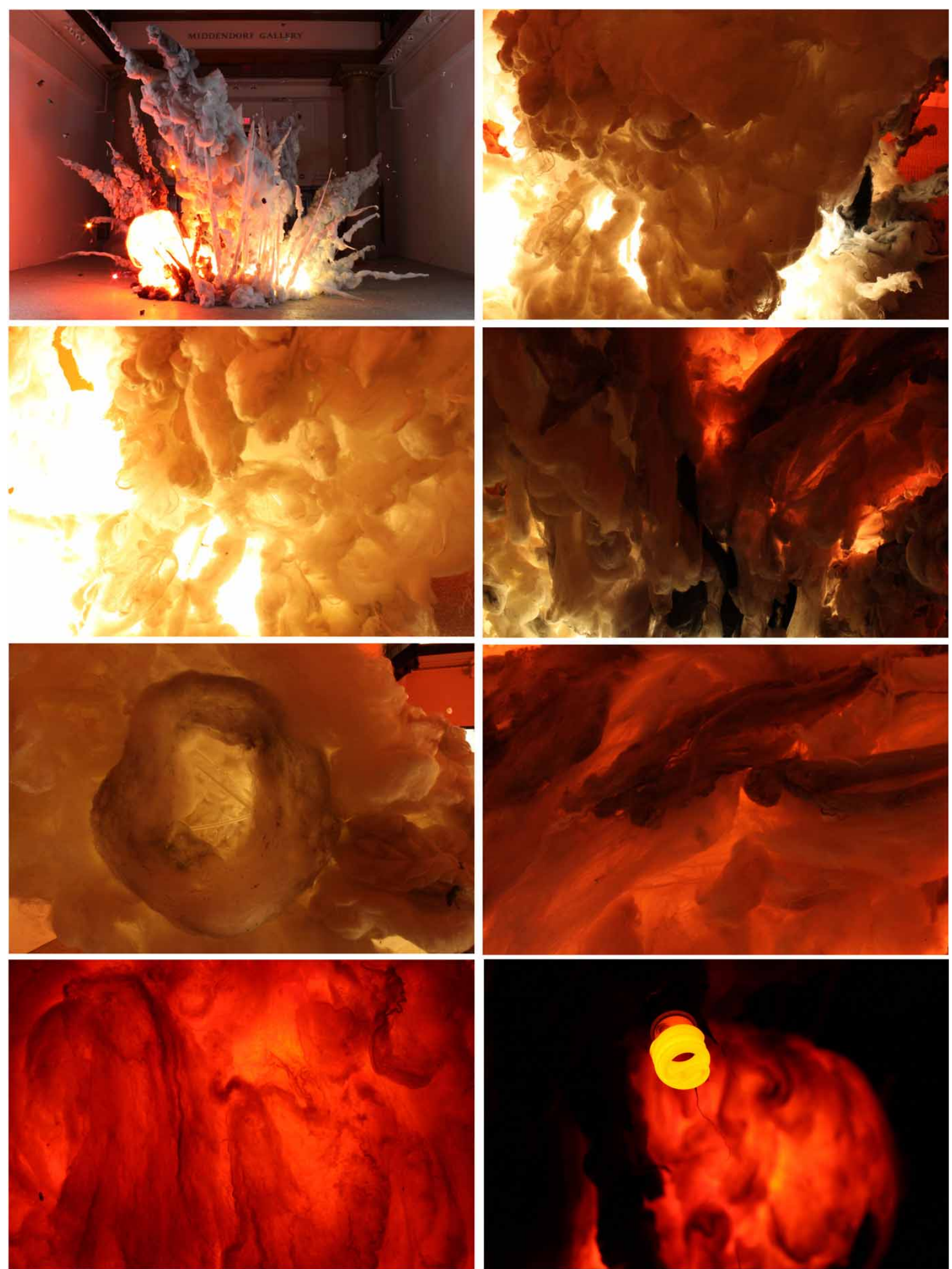

FIGURE 5 | Details of the "Silk explosion or how to destroy $10^{6}$ cocoons that will never become butterflies" (2011). Silk, MDF, electrical conduit, CFL ligthbulbs, plexiglass, shrink fast plastic. $6 \times 6 \times 3 \mathrm{~m}$. Middendorf Gallery (Baltimore). 
while I am working. I try to be free of prejudices and theoretical premises, and follow my intuition guided by the experimentation in the studio. At the end of the day, I have an empiric personality, as beautifully sung by Battiato, and life is an experiment. My practice of sculpture is not only an exterior project, but an inherent work in progress. As Cajal once said and Jonathan Keats updated, I am shaping and reshaping another important sculpture that I hope will never cease.

The brain is wider than the sky,

For, put them side by side,

The one the other will contain

With ease, and you beside.

The brain is deeper than the sea

For hold them, blue to blue

The one the other will absorb, As sponges, buckets do.

The brain is just the weight of God,

For, lift them, pound for pound

And they will differ, if they do

As syllable from sound.

Emily Dickinson (ca. 1860, published in 1921)

\section{ACKNOWLEDGMENTS}

I want to deeply thank John Peacock, Daniel Todes, Virginia Garcia-Marin, Robert Merrill, Jennifer Coster and Yasmeen Afzal for their critical and helpful comments on the manuscript.

\section{REFERENCES}

Allmeling, C., Jokuszies, A., Reimers, K., Kall, S., Choi, C. Y., Brandes, G., Kasper, C., Scheper, T., Guggenheim, M., and Vogt, P. M. (2008). Spider silk fibres in artificial nerve constructs promote peripheral nerve regeneration. Cell Prolif. 41, 408-420.

Cajal, S. R. (1894). Consideraciones generales sobre la morfología de la célula nerviosa. La Vet. Esp. 37, 257-260, 273-275, 289-291.

Cajal, S. R. (1899-1904). Textura del sistema nervioso del hombre $y$ de los vertebrados. Madrid: Imprenta y libreria de Nicolas Moya.

Cajal, S. R. (1901). Recuerdos de mi vida. Madrid: Imprenta de Hijos de Nicolas Moya.

Canon, D. (1949). Explorer of the human brain. The life of Santiago Ramón y Cajal (1852-1934). (With a memoir by S. C. Sherrington). New York, NY: Henry Schuman, Inc.

Daugman, J. (2001). "Brain metaphor and brain theory," in Philosophy and the Neurosciences, eds W. Bechel, P. Mandik, J. Mundale, and R. S. Stufflebeam (Oxford: Blackwell Publishers), 23-36.

DeFelipe, J. (2006). Brain plasticity and mental processes: Cajal again. Nat. Rev. Neurosci. 7, 811-817.
Descartes, R. (1664). Traite de l'homme. Trans. by T. Hall (1972). Treatise on Man. Cambridge, MA: Harvard University Press.

Dickinson, E. (1921). The Complete Poems of Emily Dickinson. Boston, MA: Little, Brown, and Company.

Frazzetto, G., and Anker, S. (2009). Neuroculture. Nat. Rev. Neurosci. 10, 816-821.

Freire, M., García-López, P. (2008). "Cajal: arte, science, art and microscopic technique," in The Discrete Charm of Technology Arts in Spain, ed C. Gianetti (Badajoz: MEIAC), 99-117.

Garcia-Lopez, P., Garcia-Marin, V. and Freire, M. (2010). The histological slides and drawings of cajal. Front. Neuroanat. 4, 9. doi: 10.3389/neuro.05.009.2010

Hodgkin, A., and Huxley, A. (1952). A quantitative description of membrane current and its application to conduction and excitation in nerve. J. Physiol. 117, 500-544.

Hyman, S. E. (1962). The Tangled Bank: Darwin, Marx, Frazer and Freud as Imaginative Writers. New York, NY: Atheneus.

Kuhn, T. (1962). The Structure of Scientific Revolutions. Chicago, IL: University of Chicago Press.
Lakoff, G., and Johnson, M. (1980). Metaphors We Live By. Chicago, IL: University of Chicago Press.

Todes, D. (1997). Pavlov's physiology factory. Isis 88, 205-246.

Todes, D. (2009). Global Darwin: contempt for competition. Nature 462 , 36-37. and Man a Plant. Indianapolis, IN Hackett Publishing Company.

Otis, L. (2001). The other end of the wire: uncertainties of organic and telegraphic communication. Configurations 9, 181-206.

Otis, L. (2002). The metaphoric circuit. J. Hist. Ideas 63, 105-128.

Radtke, C., Allmeling, C., Waldmann, K. H., Reimers, K., Thies, K., Schenk, H. C., Hillmer, A., Guggenheim, M., Brandes, G., and Vogt, P. M. (2011). Spider silk constructs enhance axonal regeneration and remyelination in long nerve defects in sheep. PLoS One 6, e16990. doi: 10.1371/journal.pone.0016990

Searle, J. (1984). Minds, Brains and Science. Harvard, MA: Harvard University Press.

Sherrington, C. S. (1942). Man on His Nature. Cambridge, MA: Cambridge University Press.

Skinner, B. F. (1971). Beyond Freedom and Dignity. New York, NY: A. A. Knopf.

Sontag, S. (1990). Illness as Metaphor and AIDS and its Metaphors. New York, NY: Doubleday.
Von Neumann, J. (1958). The Computer and the Brain. New Haven, CT: Yale University Press.

Young, R. M. (1985). Darwin's Metaphors. Cambrigde, MA: Cambridge University Press.

Conflict of Interest Statement: The authors declare that the research was conducted in the absence of any commercial or financial relationships that could be construed as a potential conflict of interest.

Received: 14 May 2011; accepted: 18 January 2012; published online: 09 February 2012.

Citation: Garcia-Lopez P (2012) Sculpting the brain. Front. Hum. Neurosci. 6:5. doi: 10.3389/fnhum. 2012.00005

Copyright (c) 2012 Garcia-Lopez. This is an open-access article distributed under the terms of the Creative Commons Attribution Non Commercial License, which permits non-commercial use, distribution, and reproduction in other forums, provided the original authors and source are credited. 